Int. J. Electrochem. Sci., 11 (2016) 4850 - 4864

International Journal of

ELECTROCHEMICAL

SCIENCE

WWW.electrochemsci.org

\title{
Electrochemical Evaluation of Reinforcement Concrete Exposed to Soil Type SP Contaminated with Sulphates
}

\author{
G. Santiago-Hurtado ${ }^{1}$, M.A. Baltazar-Zamora ${ }^{2, *}$, R. Galván-Martínez ${ }^{3}$, L. D. López L ${ }^{4}, F$. Zapata $G^{5}$, \\ $P$-Zambrano ${ }^{6}, C$. Gaona-Tiburcio ${ }^{6}, F$. Almeraya-Calderón ${ }^{6}$ \\ ${ }^{1}$ Doctorado en Ingeniería, FIME - Xalapa, Universidad Veracruzana, Xalapa, Veracruz, México. \\ ${ }^{2}$ Facultad de Ingeniería Civil - Xalapa, Universidad Veracruzana, Circ. G. Aguirre Beltrán S/N, Lomas \\ del Estadio, Xalapa, Veracruz, CP 91000, México. \\ ${ }^{3}$ Instituto de Ingeniería - Boca del Rio, Universidad Veracruzana, Boca del Río, Veracruz, México. \\ ${ }^{4}$ Grupo de Investigación DICSO, Instituto de Ciencias Básicas e Ingeniería, UAEH \\ ${ }^{5}$ Facultad de Ingeniería, Universidad Autónoma de Coahuila, Saltillo, Coahuila, México. \\ ${ }^{6}$ Universidad Autónoma de Nuevo León. FIME. Centro de Investigación e Innovación en Ingeniería \\ Aeronáutica, CIIIA, Carretera a Salinas Victoria Km. 2.3. C.P. 66600. Apocada. Nuevo León. México \\ *E-mail: mbaltazar@uv.mx
}

doi: $10.20964 / 2016.06 .31$

Received: 9 December 2015 / Accepted: 20 February 2016 / Published: 4 May 2016

\begin{abstract}
The present research evaluates the electrochemical behaviour of concrete exposed to SP soil type, sand from marine environment and contaminated with 1,2 and $3 \%$ de $\mathrm{MgSO}_{4}$, this experimental setup simulates what happens on the foundations of civil infrastructure as bridges, docks, highways, etc., when they are built on contaminated soils with this aggressive agent due to discharges of wastewater, marine waters or areas polluted by agrochemicals. The concrete used in making specimens of study was designed according to the ACI method 211.1, it was considered to design the concrete mixture a ratio $\mathrm{w} / \mathrm{c}=0.65\left(\mathrm{f}^{\prime} \mathrm{c}=250 \mathrm{~kg} / \mathrm{cm}^{2}\right)$, two types of cement, ordinary portland cement $(\mathrm{CPC} 30 \mathrm{R})$ and sulphate-resisting cement (CPC 30R RS), in the specimens were embedded as reinforcement bars of steel AISI 1018 and Galvanized steel. $\mathrm{E}_{\text {corr }}$ was evaluated according to the standard ASTM C-876-09 and the corrosion kinetics $\mathrm{I}_{\text {corr }}$ it was monitored by the technique of Linear Polarization Resistance (LPR), according to standard ASTM G-59-97(2009). The results of $\mathrm{E}_{\text {corr }}$ and $\mathrm{I}_{\text {corr }}$ correspond to 266 days of exposition in specimens to SP soil type contaminated with $\mathrm{MgSO}_{4}$ indicating with increasing concentration of aggressive agent to $3 \%$ it is considerably decreased the corrosion resistance of the concrete specimens produced with sulphate resisting cement and reinforced with galvanized steel.
\end{abstract}

Keywords: Soil, Concrete, Corrosion Potential, Electrochemical, Sulphates 


\section{FULL TEXT}

C) 2016 The Authors. Published by ESG (www.electrochemsci.org). This article is an open access article distributed under the terms and conditions of the Creative Commons Attribution license (http://creativecommons.org/licenses/by/4.0/). 